\title{
A descriptive epidemiological study of mastitis in 12 Irish dairy herds
}

Damien J. Barrett, Michael L. Doherty and Anne M. Healy

Department of Large Animal Clinical Studies, Faculty of Veterinary Medicine,

University College Dublin, Belfield, Dublin 4, Ireland.

Factors relating to the occurrence of mastitis were studied on 12 Irish dairy herds

Key words

Cattle,

Cows,

Mastitis,

Milking routine,

Cow housing,

Dry cow therapy. experience environmental mastitis. Herds with inadequate calving facilities, where cows spent prolonged periods on straw bedding, were likely to acquire environmental mastitis. In the majority of the herds, the selection of dry cow therapy lacked adequate planning. The majority of farmers took no action to reduce pain experienced by cows suffering mastitis. Deficiencies in parlour hygiene were evident in all herds experiencing elevation in SCC.

Irish Veterinary Journal

Volume 58: 31 - 35, 2005

\section{Introduction}

Bovine mastitis may be classified as contagious or environmental. The main contagious pathogens are Staphylococcus aureus and Streptococcus species. Although Streptococcus uberis is environmental in origin, it can be spread from cow to cow in a manner similar to that for contagious mastitis organisms. The mammary gland and udder skin act as reservoirs of infection in contagious mastitis. Infection is acquired during udder preparation or during the milking process. The presence of carrier cows in the herd, inappropriate

Corresponding author

\section{Damien Barrett}

Centre for Veterinary Epidemiology and Risk Analysis,

Faculty of Veterinary Medicine,

University College Dublin,

Belfield,

Dublin 4,

Ireland

Tel: +3531716 6148

Fax: +35317166147

Email: Damien.barrett@ucd.ie milking practices and milking machine malfunction are all known to contribute to the development of mastitis. The cow's environment is the reservoir of infection for environmental mastitis. The prevalence of environmental mastitis relates to the level of teat-end exposure to the causative agents, namely Gramnegative bacteria such as Escherichia coli, Klebsiella pneumoniae, Enterobacter aerogenes, Pseudomonas aeruginosa, and Streptococcus uberis. Coliform infections are generally of short duration. Streptococcus uberis infections often become chronic and can be very difficult to cure (Hillerton and Kliem, 2001). These bacteria survive best in wet, warm, humid and dirty conditions (Hughes, 1999). Successful management of environmental mastitis requires minimising teat-end exposure to faecal material, reducing the bacterial load on cow-lying areas and reducing bacterial survival (Hogan and Smith, 1998). There must be sufficient numbers of comfortable cubicles of an adequate size to maximize their use. Cows in the immediate prepartum period are at increased risk of acquiring environmental infections (Menzies et al., 2003). Coliform bacteria and environmental streptococci are known to colonise the udder of dry cows and may lay dormant for up to 90 days into lactation (Smith and Hogan, 1999). The majority of dry 
cow therapies are of limited value in dealing with coliform bacteria; therefore, management of cow housing to minimise teat-end exposure to such bacteria is critical to control the incidence of environmental mastitis (Smith and Hogan, 1999).

It is clear that the aetiology of mastitis is multifactorial and complex in nature, and it is probable that a number of factors may be acting together in any given herd. The objective of this study was to record and describe the characteristics of the 12 Irish dairy herds under study, and identify any deficiencies that may have predisposed the cows to mastitis.

\section{Materials and methods \\ Herd selection}

Twelve herds (Table 1) were selected for study on the basis of an increased incidence of clinical mastitis, and/or an increase in somatic cell count, where bulk milk SCC was approaching or exceeding 400,000 cells per $\mathrm{ml}$. All cows in the study were Holstein-Friesians. The herds were distributed across Ireland: three herds were situated in Co Wicklow, two herds in Co Meath, two herds in Co Kilkenny, three herds in Co Cork and one herd each in counties Kerry and Tipperary. All herds participated in milk recording schemes. Milk recording data were requested from each farmer's milk recorder before a farm visit was undertaken.

\section{On-farm evaluations}

Following examination of the milk recording data, cows with a somatic cell count in excess of 200,000 cells per $\mathrm{ml}$ in the last milk recording prior to the farm visit were identified as potentially 'problem cows' and, during the initial farm visit, milk samples were collected from them for microbiological examination (Barrett, 2004). Cow housing and calving facilities were examined. Dry cow management and dry cow therapy prior to the visitation were discussed. Milking machine service data were examined, if available. Milking was observed to detect any deficiencies in the milking routine.

\section{Data handling and analysis}

Information was gathered using a checklist. This was collated for all herds using Microsoft Excel (Microsoft Corporation, Seattle, Washington, USA).

\section{Results}

Seven of the herds were exclusively spring-calving, while the remaining five herds calved cows in both autumn and spring. This calving distribution would not accurately reflect the national situation where approximately $90 \%$ of Irish cows calve in the spring months (Anon, 2002a). The high proportion of autumn-calving herds in this study reflects the geographical spread of farms, as the farms close to large urban centres produce for the liquid milk market. Of the five farms within 40 miles of Dublin, four calved in the autumn and spring. Of the remaining seven herds, only one calved cows in the autumn.

\section{TABLE 1: Herd size, average herd yield, calving pattern of the $\mathbf{1 2}$ herds in the study}

\begin{tabular}{|cccc|}
\hline Herd & $\begin{array}{c}\text { Number } \\
\text { of cows }\end{array}$ & $\begin{array}{c}\text { Milk yield } \\
(\text { litres })\end{array}$ & $\begin{array}{c}\text { Calving } \\
\text { pattern }\end{array}$ \\
\hline A & 52 & 7200 & A \\
\hline B & 55 & 5400 & S \\
\hline C & 44 & 5850 & S \\
\hline D & 125 & 6075 & A \\
\hline E & 54 & 6030 & S \\
\hline F & 57 & 5625 & S \\
\hline G & 56 & 7515 & A \\
\hline H & 67 & 6075 & S \\
\hline I & 140 & 7200 & A \\
\hline J & 85 & 6057 & S \\
\hline K & 57 & 6750 & S \\
\hline L & 49 & 7425 & A \\
\hline
\end{tabular}

*Calving pattern: $\mathrm{S}$ - spring; A - split calving (spring and autumn).

Milk from this farm was destined for the manufacture of yoghurt, rather than butter or casein.

\section{Housing}

Cows were housed in cubicles in all 12 herds. The mean number of cubicles per 100 cows was 100.25 , with a range of 60 to 129. Five herds (C, D, F, I and L) had less than one cubicle per cow. All herds except Herd I had cubicle mats, although the mats in Herd G covered only the front half of the cubicles. In Herd G, there were bars in place at the end of cubicle beds, which allowed water to gather on them.

Cubicle length varied from $205 \mathrm{~cm}$ to $224 \mathrm{~cm}$, with six herds having cubicles 210 to $220 \mathrm{~cm}$ in length. Cubicles varied from $100 \mathrm{~cm}$ to $127 \mathrm{~cm}$ wide; in three herds they were less than $110 \mathrm{~cm}$ wide. Bedding material was applied to cubicle beds in 10 of the 12 herds, and sawdust was the most commonly used bedding material. The majority of herds cleaned down cubicles occupied by lactating cows twice daily, while there was less attention to the cleaning of cubicles occupied by dry cows. Likewise, lime was applied to the cubicles occupied by lactating cows more frequently than it was to cubicles of dry cows.

Straw yards, exposed to the prevailing wind, were used to house dry cows and heifers in Herds I and L. This resulted in rain being blown onto the straw beds, wetting them. Yards were bedded as necessary in Herd I and every second day in Herd L. The straw yards were cleaned out twice over the calving season in Herd I and monthly in herd L. In Herd A, cows were housed in a straw-bedded yard for the last two weeks of the dry period with a view to enhancing animal welfare. This was bedded daily, and cleaned out every few weeks. This, too, was exposed to wind and rain, resulting in wetting of the straw beds. Herd D, faced with insufficient cubicles for the number of cows, opted 


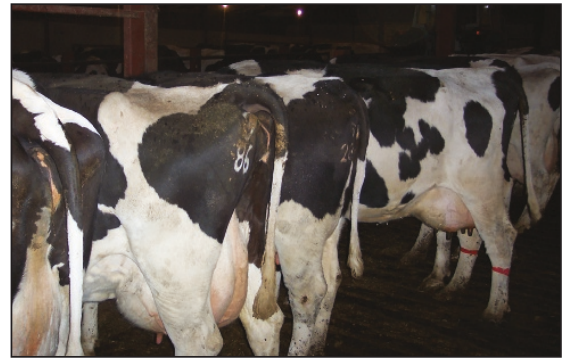

Cubicles should be designed to be comfortable for cows, to be in constant use but to stay reasonably clean.

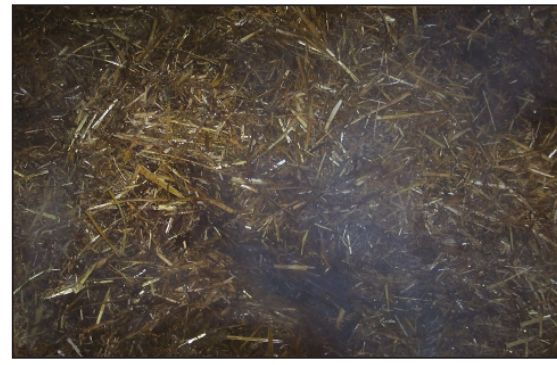

Straw yard beds compost at around $40^{\circ} \mathrm{C}$ and are associated with Strep. uberis infections.

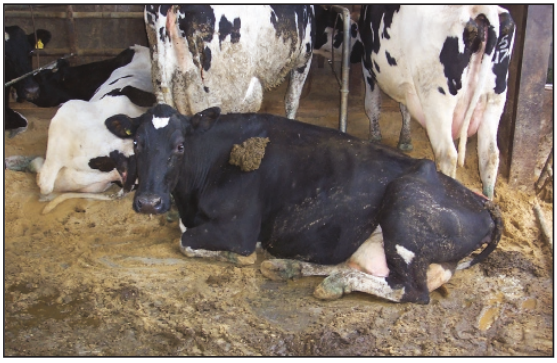

Cubicles of unsuitable dimensions encourage cows to lie in the passageway, with a consequent risk of mastitis. for a New Zealand style lie-out pad, consisting of wooden bark. This was first used in 2000. However, it was poorly drained, resulting in a build up of effluent on the surface of the bed. The lie-out pad was overstocked, as the farmer admitted that he had 50 cows on a pad designed for 30 .

The number of calving pens per 100 cows varied from two to nine; the average number per farm was five. There was no calving pen as such in Herd D: the cows calved in a communal strawbedded yard. Calving pens varied in size from 8 square metres up to 20 square metres, with an average area of 14.2 square metres. Straw was used as the bedding material in all herds. Calving pens were exposed to wind and rain in herds A, I and L. In some herds fresh bedding was applied to the beds after each calving, in other herds 'every few days'. The frequency at which pens were cleaned out varied from after every three or four calvings to once per calving season. The duration of cows' stay in calving pens varied between one and 11 days.

\section{Dry cow therapy}

Dry cow therapy (DCT) was administered to all cows at drying off in each of the 12 herds. Cows were dried off abruptly in 10 of the 12 herds, while gradual drying off was practiced in Herds B and G. Parenteral antimicrobial therapy was combined with intramammary therapy in Herd B, where high SCC cows received a single injection of tylosin (Tylan, Elanco Animal Health). Cloxacillin-based products were used in eight herds, cephalonium in three herds and framycetin/penethmate/ penicillin in one herd. In four herds, there was no reason given for selecting the product used. Farmers B and C selected a sealant product combined with a cloxacillin-based product (to create a seal at the teat end along with antimicrobial activity within the gland). Three farmers selected the dry cow therapy on the basis of their veterinary surgeons' advice. Farmers $G$ and $\mathrm{H}$ selected their dry cow therapy based on its duration of activity. Farmer D admitted that he chose dry cow therapy based on marketing information from a salesperson. The duration of the dry period varied from 42 to 100 days.

\section{Clinical mastitis records}

Four herds maintained written records of cases of clinical mastitis. Results of bacteriological examination of milk samples taken prior to the initial visitation were available in five herds.

\section{Milking machine}

Herringbone milking machines were used in all 12 herds. Milking machines were serviced annually on all farms. An investigation subsequent to the initial visit by the farm milking machine technician indicated the vacuum pump in Herd E required replacement. In Herd L, problems relating to pulsator function were detected, by the milking machine technician, immediately following the initial visit to the herd.

\section{Milking routine}

Cows were keen to enter the parlour in all herds. Milkers wore gloves in only three herds. Routine washing was carried out in Herd $\mathrm{B}$ only, with the remaining herds washing only if teats were excessively dirty. Only in Herds $\mathrm{C}$ and $\mathrm{H}$ were teats dried if they were washed. Pre-milking teat disinfection was not practised in any of the 12 herds. Automatic cluster removers were not in operation in any of the herds. Clusters appeared to be aligned properly in all herds. Clusters were disinfected after each cow in Herds $\mathrm{C}$ and $\mathrm{H}$. A separate cluster was used for 'problem cows' in Herds D and I, while 'problem cows' were segregated and milked last in Herds E and L. Cows in Herds B, $\mathrm{J}$, and $\mathrm{L}$ were regularly milked by two people, while each of the remaining herds had only one milker. Vacuum was turned off prior to cluster removal in all herds except herd L.

\section{Post-milking teat disinfection (PMTD)}

Teat disinfection was not done in Herd $\mathrm{L}$ at the initial visit, while in Herds A, E, and $\mathrm{K}$, teat disinfection had been put in place shortly prior to the initial visit. In all other herds, teat disinfection had been undertaken routinely for a number of years. Teat-dipping was carried out on two farms while teat spraying was carried out on the remainder, using chlorhexidine or iodophor-based teat disinfectants. The average volume of PMTD applied per cow per milking was $7.06 \mathrm{ml}$ (range 0 to $17 \mathrm{ml}$ per milking). Cows had the opportunity to remain standing for up to 30 minutes after milking in herds $\mathrm{E}$ and $\mathrm{K}$. 


\section{Discussion}

The selection criteria for this study ensured that all 12 farms had deficiencies in one or more areas in their approach to mastitis control. The multifactorial nature of the aetiology of mastitis creates considerable difficulties in interpreting field data, and such difficulties were encountered in analysing the data from this study.

Environmental mastitis was regarded as the main problem on six farms, four of which had less than the recommended ratio of 110 cubicles per 100 cows (Britten, 1994), with Herd D having only 60 cubicles per 100 cows. The other two herds had a ratio of 113 cubicles to 110 cows, but management practices detrimental to udder health were identified. In Herd G, there was a metal bar in place at the back of the cubicle beds, which led to the retention of water on the cubicle ends, creating optimal conditions for bacterial survival and proliferation. In Herd A, cows were housed in a wind-exposed straw yard for a week before calving; such exposure to wind and rain brought about the wetting of the straw beds. This yard was often densely stocked and cleaned out only fortnightly. Straw-bedded yards are associated with increased incidence of environmental mastitis, particularly mastitis caused by S. uberis (Bramley, 1982; Ward et al., 2002). There is uncertainty over the optimal stocking density, quantity and quality of straw and frequency of cleaning out straw beds (Blowey and Edmondson, 2000). Two of the three herds with straw-bedded yards were exposed to the prevailing winds, resulting in wetting of the straw; both experienced considerable difficulties with mastitis caused by $S$. uberis.

Leonard and O'Connell (1997) recommended that cubicles should be $230 \mathrm{~cm}$ long and $110 \mathrm{~cm}$ wide; in this study none of the herds met the criterion for cubicle length, while the criterion for width was met in all but three herds. Smaller cubicle dimensions will result in reduced occupancy rates (Leonard and O'Connell, 1997). Cubicle mats encourage cubicle usage, increasing lying time by up to $20 \%$ as they provide a soft insulated surface for cows to lie on (Dumelow, 1995). Cubicle mats were in use in all herds except Herd I, although the efficacy of the mats in Herd G was questionable, because they covered only the front $120 \mathrm{~cm}$ of the cubicle, with the remaining $94 \mathrm{~cm}$ toward the back of the cubicle left uncovered.

The application of bedding material onto cubicle mats, as was the case in nine herds, is thought to reduce friction between the skin on cows' limbs and the mats (Blowey and Edmondson, 2000). Dry organic bedding materials contain very few mastitis pathogens when applied to cubicle beds, but these bacterial populations quickly expand and reach maximal levels after 24 hours, even where bedding does not appear soiled (Hogan and Smith, 1998). Therefore, cleaning the cubicles and applying bedding daily should restrict the bacterial load on the cubicles. Lime is known to reduce the bacterial load on cubicle beds (Hughes, 1999). Ten herds used bedding materials on cubicles, nine in the form of sawdust, one as shredded paper; however, it was not possible to correlate these practices with the incidence of mastitis.

As cows are most highly susceptible to contracting environmental mastitis in the periods immediately preceding and following calving, it is imperative that a high standard of hygiene is maintained throughout this period of risk (Smith and Hogan, 1999). Because of the varying size of calving pens, number of pens per 100 cows, the frequency of bedding, the quality of straw, duration of stay and frequency of clean out, it was not possible to draw any consistent conclusions. This was a reflection of the wide variation in procedures and facilities on the various farms. However, it was clear that a herd with insufficient and small straw-bedded calving area, where overstocked cows stayed for more than two days, was likely to have problems with environmental mastitis.

Although all cows in the study received dry cow therapy, it was apparent that little thought or planning went into the selection of product. In four herds, the dry period extended up to between 90 and 100 days and, interestingly, only one of these herds used a teat seal product. None of the antimicrobial dry cow therapies currently on the market in Ireland would be effective for such extended periods, with no purely antimicrobial-based product active for longer than 70 days. Teat sealants have been shown to be as effective as conventional dry cow therapy in preventing the acquisition of intramammary infection in non-infected quarters during the dry period (Woolford et al., 1998; Huxley et al., 2002). Intramammary therapy was combined with parenteral therapy for a number of cows in only one herd, indicating limited awareness of combined therapy. However, the selection criteria employed were likely to select chronic long-standing infections and the sub-therapeutic doses used were unlikely to bring about a favourable response.

Fitzpatrick et al. (1999) concluded that cows have an increased sensitivity to pain even with mild mastitis and recommended that pain-relieving methods be employed to reduce pain and return the udder to normal function as quickly as possible. The fact that only one farmer (D) considered using therapy for pain relief indicates that the farmers within the study group did not see pain relief as a priority in treating mastitis. It also indicates that education may be required to make farmers aware that mastitis is a remarkably painful condition.

Logan (1993) emphasised the need for proper milking machine maintenance to prevent the acquisition of subclinical mastitis. While the milking machine was serviced annually in each of the herds, faults in vacuum reserve (Herd E) and in pulsation (Herd L) were discovered subsequent to the initial visit.

While EU directive 92/46/ECC requires all cows producing milk for human consumption to be foremilked, this was done in five herds only, while udders were palpated before applying clusters in another two herds. Therefore, in five of the 12 herds there was no routine procedure for the early detection of 
mastitis, a cornerstone of mastitis control. Foremilking and the disposal of abnormal milk is the most efficient method of reducing the bulk milk cell count of problem herds (Rasmussen, 2000). Many farmers have discontinued foremilking to save time. However, proper teat cleaning and foremilking should provide sufficient pre-milking stimulation (Hamann, 1997), enhance the milk let-down reflex and result in faster milking (Anon., 2002b).

In six of the 12 herds, cluster disinfection, a separate cluster for mastitic cows, and segregation of problem cows were used to reduce the spread of infection from infected cows to noninfected cows.

Post-milking teat disinfection (PMTD) is a well-established method of preventing the spread of contagious mastitis pathogens during milking (Farnsworth, 1980) and its efficacy is beyond doubt. However, to be effective, adequate amounts of disinfectant must be applied. It is recommended that $10 \mathrm{ml}$ of teat dip and $15 \mathrm{ml}$ of teat spray be applied to teats immediately after milking to maximise the efficiency of PMTD (Edmondson, 2002). Insufficient volumes of teat disinfectant were applied in all but one of the 12 herds. Teat spraying was preferred to teat dipping, as it was considered to be quicker and less labour intensive than dipping.

It is recommended that during the housed period measures should be taken to ensure that teat ends are closed before cows lie down, thereby preventing entry of pathogens up the teat canal (Hamann, 1997). Only two of the 12 herds adopted that recommendation.

\section{Conclusions}

1. Herds with less than 110 cubicles per 100 cows were more likely to experience environmental mastitis.

2. Herds with inadequate calving facilities along with prolonged periods on straw bedding were more likely to acquire environmental mastitis.

3. In the majority of the herds, the selection of dry cow therapy lacked adequate planning.

4. The majority of farmers took no action to reduce pain experienced by cows with mastitis.

5. Deficiencies in parlour hygiene were identified in all herds experiencing sub-clinical mastitis. Failure to employ a routine procedure for early detection of clinical mastitis and inadequate post-milking teat disinfection were identified as major contributory factors to this occurrence.

\section{References}

Anon. (2002a). Irish Cattle Breeding Statistics 2002. Bandon: Irish Cattle Breeding Federation.

Anon. (2002b). Effects of forestripping on milk flow rates. Udder Topics 25 (5): 3.

Barrett, D.J. (2004). A Study of Mastitis in Irish Dairy Herds. Masters Thesis, National University of Ireland.
Blowey, R.W. and Edmondson, P.W. (2000). The environment and mastitis. In Practice 22: 382- 394.

Bradley, A.J. and Green, M.J. (2001). An investigation of the impact of intramammary antibiotic dry cow therapy on clinical coliform mastitis. Journal of Dairy Science 84: 1632-1639.

Bramley, A.J. (1982). Sources of Streptococcus uberis in the dairy herd. Journal of Dairy Research 49: 369-373.

Britten, A.M. (1998). Delivering mastitis control systems to your clients. Large Animal Practice 10: 14-21.

Dumelow, J. (1995). Testing cubicle mats for dairy cows. Agricultural Engineer 50: 17-21.

Edmondson, P.W. (2002). Teat dipping trouble. Proceedings of the British Mastitis Conference, pp 15-19.

Farnsworth, R.J. (1980). Role of teat dips in mastitis control. Journal of the American Veterinary Medical Association 176: 1116-1118.

Fitzpatrick, J.L., Young, F.J., Eckersall, D., Logue, D.N., Knight, C.H. and Nolan, A. (1999). Mastitis - a painful problem. Cattle Practice 7: 225-226.

Hamann, J. (1997). Guidelines for evaluation of the milking process. Bulletin of the IDF 321, pp 26-30.

Hillerton, J.E. and Kliem, K.E. (2001). Aggressive therapy of clinical Streptococcus uberis mastitis. Proceedings of the Second International Symposium on Mastitis and Milk Quality, pp234-237.

Hogan, J.S. and Smith, K.L. (1998). Risk factors associated with environmental mastitis. National Mastitis Council Annual Meeting Proceedings, pp93-97.

Hughes, J. (1999). Bedding systems and mastitis. Proceedings of the British Mastitis Conference, pp73-78.

Huxley, J.N., Green, M.J., Green, L.E. and Bradley, A.J. (2002). Evaluation of the efficacy of an internal teat sealer during the dry period. Journal of Dairy Science 85: 551-561.

Leonard, F.C. and O'Connell, J.M. (1997). Cubicle housing conditions and cow comfort. Irish Veterinary Journal 50: 675-682.

Logan, E.F. (1993). Introducing a national mastitis control programme. Proceedings of the British Mastitis Conference, pp50-61.

Menzies, F.D., Gordon, A.W., McBride, S.H. and Goodall, E.A. (2003). Risk factors for toxic mastitis in cows. Veterinary Record 152: 319-322.

Rasmussen, M. (2000). A review of milking preparation: the science. National Mastitis Council Annual Meeting Proceedings, pp104-110.

Smith, K.L. and Hogan, J.S. (1999). Managing dry cows to control mastitis. Proceedings of the British Mastitis Conference, pp79- 86.

Ward, W.R., Hughes, J.W., Faull, W.B., Cripps, P.J., Sutherland, J.P. and Sutherst, J.E. (2002). Observational study of temperature, $\mathrm{pH}$ and bacteria in straw bedding, and faecal consistency, cleanliness and mastitis in four dairy herds. Veterinary Record 151: 199-206.

Woolford, M.W., Williamson, J.H., Day, A.M. and Copeman, P.J.A. (1998). The prophylactic effect of a teat sealer on bovine mastitis during the dry period and the following lactation. New Zealand Veterinary Journal 46: 12-19.

Images courtesy of Peter Edmondson, Shepton Veterinary Group, Somerset, United Kingdom. 